\title{
Highly multiplexed quantifications of 299 somatic mutations in colorectal cancer patients by automated MALDI-TOF mass spectrometry
}

\author{
Chang $\mathrm{Xu}^{1,2 \dagger}$, Danli Peng ${ }^{2,3 \dagger}$, Jialu Li $i^{2,3}$, Meihua Chen ${ }^{2,3}$, Yujie Hu ${ }^{2,3}$, Mingliang Hou ${ }^{2,3}$, Qingjuan Shang ${ }^{2,3}$,

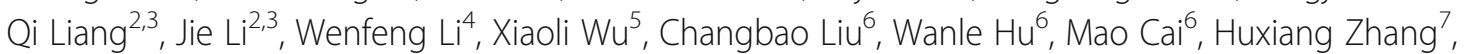 \\ Guorong Chen ${ }^{7}$, Lingling Y $\mathrm{u}^{8}$, Xiaoqun Zheng ${ }^{2,8}$, Feizhao Jiang ${ }^{1}$, Ju Luan ${ }^{2,3^{*}}$, Shengnan Jin $^{2,3^{*}}$ and \\ Chunming Ding ${ }^{2,3^{*}}$ (1)
}

\begin{abstract}
Background: Detection of somatic mutations in tumor tissues helps to understand tumor biology and guide treatment selection. Methods such as quantitative PCR can analyze a few mutations with high efficiency, while next generation sequencing (NGS) based methods can analyze hundreds to thousands of mutations. However, there is a lack of cost-effective method for quantitatively analyzing tens to a few hundred mutations of potential biological and clinical significance.
\end{abstract}

Methods: Through a comprehensive database and literature review we selected 299 mutations associated with colorectal cancer. We then designed a highly multiplexed assay panel (8-wells covering 299 mutations in 109 genes) based on an automated MADLI-TOF mass spectrometry (MS) platform. The multiplex panel was tested with a total of 319 freshly frozen tissues and 92 FFPE samples from 229 colorectal cancer patients, with 13 samples also analyzed by a targeted NGS method covering 532 genes.

Results: Multiplex somatic mutation panel based on MALDI-TOF MS detected and quantified at least one somatic mutation in 142 patients, with KRAS, TP53 and APC being the most frequently mutated genes. Extensive validation by both capillary sequencing and targeted NGS demonstrated high accuracy of the multiplex MS assay. Out of 35 mutations tested with plasmid constructs, sensitivities of 5 and 10\% mutant allele frequency were achieved for 19 and 16 mutations, respectively.

Conclusions: Automated MALDI-TOF MS offers an efficient and cost-effective platform for highly multiplexed quantitation of 299 somatic mutations, which may be useful in studying the biological and clinical significance of somatic mutations with large numbers of cancer tissues.

Keywords: Somatic mutation, Colorectal cancer, MALDI-TOF mass spectrometry, Multiplex detection

\footnotetext{
*Correspondence: luanluanjuju@163.com; snjin1997@qq.com;

cmding@gmail.com

${ }^{\dagger}$ Chang Xu and Danli Peng are co-first authors.

${ }^{2}$ School of Laboratory Medicine and Life Sciences, Wenzhou Medical University, Wenzhou, Zhejiang Province, China

Full list of author information is available at the end of the article
}

(c) The Author(s). 2020 Open Access This article is licensed under a Creative Commons Attribution 4.0 International License, which permits use, sharing, adaptation, distribution and reproduction in any medium or format, as long as you give appropriate credit to the original author(s) and the source, provide a link to the Creative Commons licence, and indicate if changes were made. The images or other third party material in this article are included in the article's Creative Commons licence, unless indicated otherwise in a credit line to the material. If material is not included in the article's Creative Commons licence and your intended use is not permitted by statutory regulation or exceeds the permitted use, you will need to obtain permission directly from the copyright holder. To view a copy of this licence, visit http://creativecommons.org/licenses/by/4.0/ The Creative Commons Public Domain Dedication waiver (http://creativecommons.org/publicdomain/zero/1.0/) applies to the data made available in this article, unless otherwise stated in a credit line to the data. 


\section{Background}

The cancer genomes carry many different genomic alterations including somatic mutations. Most notably, driver mutations are causally implicated in oncogenesis. They have conferred a growth advantage on the cancer cells [1]. Increasing number of mutations are being characterized for better treatment selection and prognosis [2]. In non-small cell lung cancer, for example, patients with epidermal growth factor receptor $(E G F R)$ mutation are likely to benefit from tyrosine kinase inhibitors (TKIs) [3]. On the opposite, colorectal cancer patients with KRAS or NRAS mutations should not be treated with either EGFR-inhibitor Cetuximab [4] or Panitumumab [5].

Several methods are available for the detection of tumor somatic mutations. Next generation sequencing (NGS) is widely adopted as a discovery tool for somatic mutation analysis in cancer [6]. Using NGS, The Cancer Genome Atlas (TCGA) presents genomic alternations identified from over 11,000 tumor samples from 33 cancer types, providing valuable insights into new targets for drug development, treatment selection, or even combination therapies for personalized medicine [7]. While NGS methods can analyze hundreds to tens of thousands mutations [8], methods such as qPCR or digital PCR are ideal for analyzing a few clinically important mutations with high efficiency and cost-effectiveness [9, 10]. However, as biologically and clinically important mutations for many cancer types continue to be identified, there is a growing unmet need to cost-effectively and quantitatively analyze tens to a few hundred of mutations, in highly heterogenous cancer tissues where mutant allele frequency can be highly variable.

The MassARRAY platform, based on automated MALDI-TOF mass spectrometry, is suitable to meet this growing need due to its high multiplex capability, flexibility for both sample size and mutation number, quantification capability, and automation in sample processing and data analysis [11]. The MassARRAY can detect up to 40 mutations in a single well on a 96 or 384-well plate.

In this report, we developed and validated an 8-well panel covering 299 most common somatic mutations in colorectal cancer (CRC). Such multiplex level may be sufficient for detecting virtually all clinically relevant mutations in a cancer type, with costeffectiveness and turnaround time desirable in reallife clinical settings.

\section{Method}

\section{Patients recruitment}

Patients diagnosed with colorectal cancer were recruited with informed consent between July 2015 and June 2019 from the First Affiliated Hospital and the Second Affiliated Hospital of Wenzhou Medical University, China.
Exclusion criteria include more than two pathological types, metastasis, treated with neoadjuvant chemotherapy or immunotherapy before surgery, or any cancer within the past 5 years. Tumor stages were determined according to the 8th edition of the American Joint Committee on Cancer (AJCC). The study was approved by the ethics committee of Wenzhou Medical University and its affiliated hospital.

\section{Sample collection and DNA extraction}

Resections or biopsies of primary solid tumors and adjacent normal tissues located $2-\mathrm{cm}$ away from the tumor tissue, were taken immediately after surgery, snap frozen in liquid nitrogen, and stored at $-80^{\circ} \mathrm{C}$. DNA was extracted from tissue using the QIAamp DNA mini kit (Qiagen, Hilden, Germany) according to the manufacturer's instruction, and stored at $20{ }^{\circ} \mathrm{C}$ for further use. The DNA concentration was quantified by NanoDrop One (Thermo Fisher Scientific, Foster City, CA, USA).

FFPE tumor samples were analyzed by hematoxylinand-eosin (H\&E) staining to determine tumor purity. For each FFPE tissue, 20 slices of $10-\mu$ m-thick sections were used for DNA extraction with the QIAamp DNA FFPE Tissue kit (Qiagen). Concentration of DNA was determined by a Qubit 3.0 Fluorometer (Thermo Fisher Scientific).

\section{CRC mutation panel design}

The mutations were selected for either of the following three reasons: 1) present in at least two of the following three sources for CRC samples: TCGA (https://cancergenome.nih.gov/); International Cancer Genome Consortium (ICGC) database (https://icgc.org/); and publication by Muzny DM et al. [12]; 2) potential resistance to CRC targeted therapy based on My Cancer Genome (http://www.mycancergenome.org), or 3) reported in a commercial cancer panel [13].

The CRC mutation panel was designed with Assay Designer software (MassARRAY Typer, Version 4.0, Agena Biosciences, San Diego, CA, USA), with primer sequences not overlapping known single nucleotide polymorphisms whenever possible.

\section{CRC mutation detection and quantification by MALDI-TOF MS}

CRC Mutation detection was optimized and performed by MassARRAY Analyzer 4 with CPM (Agena Biosciences). All primers were purchased from Integrated DNA Technologies (Integrated DNA Technologies, Coralville, IA, USA). All reagents were purchased from Agena Bioscience unless otherwise specified. Briefly, tissue genomic DNA was amplified by multiplex PCR. Shrimp alkaline phosphatase treatment was performed 
to inactivate surplus nucleotides. A primer extension reaction (iPLEX Pro) was performed with mass-modified terminator nucleotides, and the product was spotted on SpectroCHIP. Wild-type and mutant alleles were then discriminated by molecular weights determined by MassARRAY analyzer.

Allele calls were performed with MassARRAY Typer Analyzer software (Typer 4.0.26). Additionally, at least

Table 1 Patient characteristics

\begin{tabular}{|c|c|c|c|}
\hline Characteristic & $\begin{array}{l}\text { All patients } \\
(N=229)(\%)\end{array}$ & $\begin{array}{l}\text { Frozen tissue cohort } \\
(N=183)(\%)\end{array}$ & $\begin{array}{l}\text { FFPE tissue cohort } \\
(N=46)(\%)\end{array}$ \\
\hline \multicolumn{4}{|l|}{ Age - no. } \\
\hline$<50$ & $20(8.7)$ & $17(9.3)$ & $3(6.5)$ \\
\hline $50-70$ & $124(54.1)$ & $101(55.2)$ & $23(50.0)$ \\
\hline$>70$ & $85(37.2)$ & $65(35.3)$ & $20(43.5)$ \\
\hline \multicolumn{4}{|l|}{ Gender - no. } \\
\hline Male & $145(63.3)$ & $113(61.7)$ & $32(69.6)$ \\
\hline Female & $84(36.7)$ & $70(38.3)$ & $14(30.4)$ \\
\hline \multicolumn{4}{|l|}{ Clinical stage - no. } \\
\hline । & $53(23.2)$ & $34(18.6)$ & $19(41.3)$ \\
\hline$\|$ & $69(30.1)$ & $59(32.3)$ & $10(21.7)$ \\
\hline III & $82(35.8)$ & $71(38.8)$ & $11(24.0)$ \\
\hline IV & $25(10.9)$ & $19(10.4)$ & $6(13.0)$ \\
\hline \multicolumn{4}{|l|}{ Location sampled - no. } \\
\hline Rectum & $177(77.3)$ & $140(76.5)$ & $37(80.5)$ \\
\hline Left Colon & $19(8.3)$ & $17(9.3)$ & $2(4.3)$ \\
\hline Right Colon & $21(9.2)$ & $16(8.7)$ & $5(10.9)$ \\
\hline Rectosigmoid Junction & $12(5.2)$ & $10(5.5)$ & $2(4.3)$ \\
\hline \multicolumn{4}{|l|}{ Differentiation - no. } \\
\hline Well & $13(5.7)$ & $12(6.6)$ & $1(2.2)$ \\
\hline Moderate & $180(78.6)$ & $145(79.2)$ & $35(76.0)$ \\
\hline Poor & $28(12.2)$ & $19(10.4)$ & $9(19.6)$ \\
\hline Unknown ${ }^{a}$ & $8(3.5)$ & $7(3.8)$ & $1(2.2)$ \\
\hline \multicolumn{4}{|l|}{ Metastatic sites - no. } \\
\hline Liver only & $19(8.3)$ & $15(8.2)$ & $4(8.7)$ \\
\hline Lung only & $2(0.9)$ & $1(0.5)$ & $1(2.2)$ \\
\hline Liver and Lung & $1(0.4)$ & $1(0.5)$ & $0(0.0)$ \\
\hline Bladder & $1(0.4)$ & $1(0.5)$ & $0(0.0)$ \\
\hline Brain & $1(0.4)$ & $1(0.5)$ & $0(0.0)$ \\
\hline \multicolumn{4}{|l|}{ Treatment after surgery - no. } \\
\hline With adjuvant therapy & $129(56.3)$ & 109 (59.6) & $20(43.5)$ \\
\hline Without adjuvant therapy & $96(42.0)$ & $74(40.4)$ & $22(47.8)$ \\
\hline NA & $4(1.7)$ & $0(0.0)$ & $4(8.7)$ \\
\hline \multicolumn{4}{|l|}{ Tumor size - cm } \\
\hline Median (range) & $4(1.5-13)$ & $4(1.5-13)$ & $4(1.5-12)$ \\
\hline \multicolumn{4}{|l|}{ CEA - ng/mL } \\
\hline $0.0-5.0$ & $150(65.5)$ & $125(68.3)$ & $25(54.3)$ \\
\hline$>5.0$ & $74(32.3)$ & $53(29.0)$ & $21(45.6)$ \\
\hline N/A & $5(2.2)$ & $5(2.7)$ & $0(0.0)$ \\
\hline
\end{tabular}

${ }^{a}$ Reported as mucinous adenocarcinomas 
two investigators independently reviewed the mass spectra to further confirm the automated calls by the software. To estimate mutant allele frequency, the heights of raw spectral peaks corresponding to the wild-type and mutation allele were quantified. Mutation allele frequency was estimated by calculating mutant peak /(mutant peak + wild type peak).

\section{Targeted NGS and data analysis}

Genomic DNA was fragmented to an average size of 200 to $500 \mathrm{bp}$ using Bioruptor Pico sonication device (Diagenode, Denville, NJ, USA). Sequencing libraries were prepared using the KAPA LTP Library Preparation Kit for Illumina (Kapa Biosystems, Wilmington, MA, USA) according to manufacturer's suggestions. Hybridizationbased target enrichment was carried out with xGen PanCancer Panel v2.4 (532 cancer-relevant genes), and xGen Lockdown Hybridization and Wash Reagents Kit (Integrated DNA Technologies). Captured libraries were amplified and purified using Agencourt AMPure XP Beads (Beckman Coulter, Atlanta, GA, USA). Concentrations and qualities of DNA libraries were analyzed by the Agilent High Sensitivity DNA Kit (Agilent Technologies, Santa Clara, CA, USA).

The libraries were paired-end sequenced on the Illumina HiSeq X platform (Illumina, San Diego, CA, USA) according to the manufacturer's instructions. Sequencing adapters and low quality bases were trimmed from raw sequencing reads using Trim Galore (v0.4.1; https:// github.com/FelixKrueger/TrimGalore). The filtered reads were then mapped to the reference Human Genome (hg38) using BWA-MEM (v0.7.12; https://github. $\mathrm{com} / \mathrm{lh} 3 / \mathrm{bwa} /$ tree/master/bwakit) with the default settings. The GATK (v4.0.12.0; https://software.broadinstitute.org/gatk/) was used for single nucleotide variation (SNV) identifications. SNV calls with at least $2.5 \%$ variant allele frequency (VAF) were retained, followed by annotation using ANNOVAR [14].

\section{Mutation validation by capillary sequencing}

A subset of samples were selected for Sanger sequencing to validate MS results. The capillary sequencing was performed with the BigDye Terminator Cycle Sequencing Kit and ABI 3730 Genetic Analyzer (Thermo Fisher Scientific).

\section{Statistical analysis}

Statistical analyses were performed with IBM SPSS Statistics 20.0. The $\chi^{2}$ test or Fisher exact test were used to compare baseline categorical variables, and the KruskalWallis test was used to analyze the association between mutation and tumor size. The Cox proportional-hazards model of multivariate analysis was performed to analyze

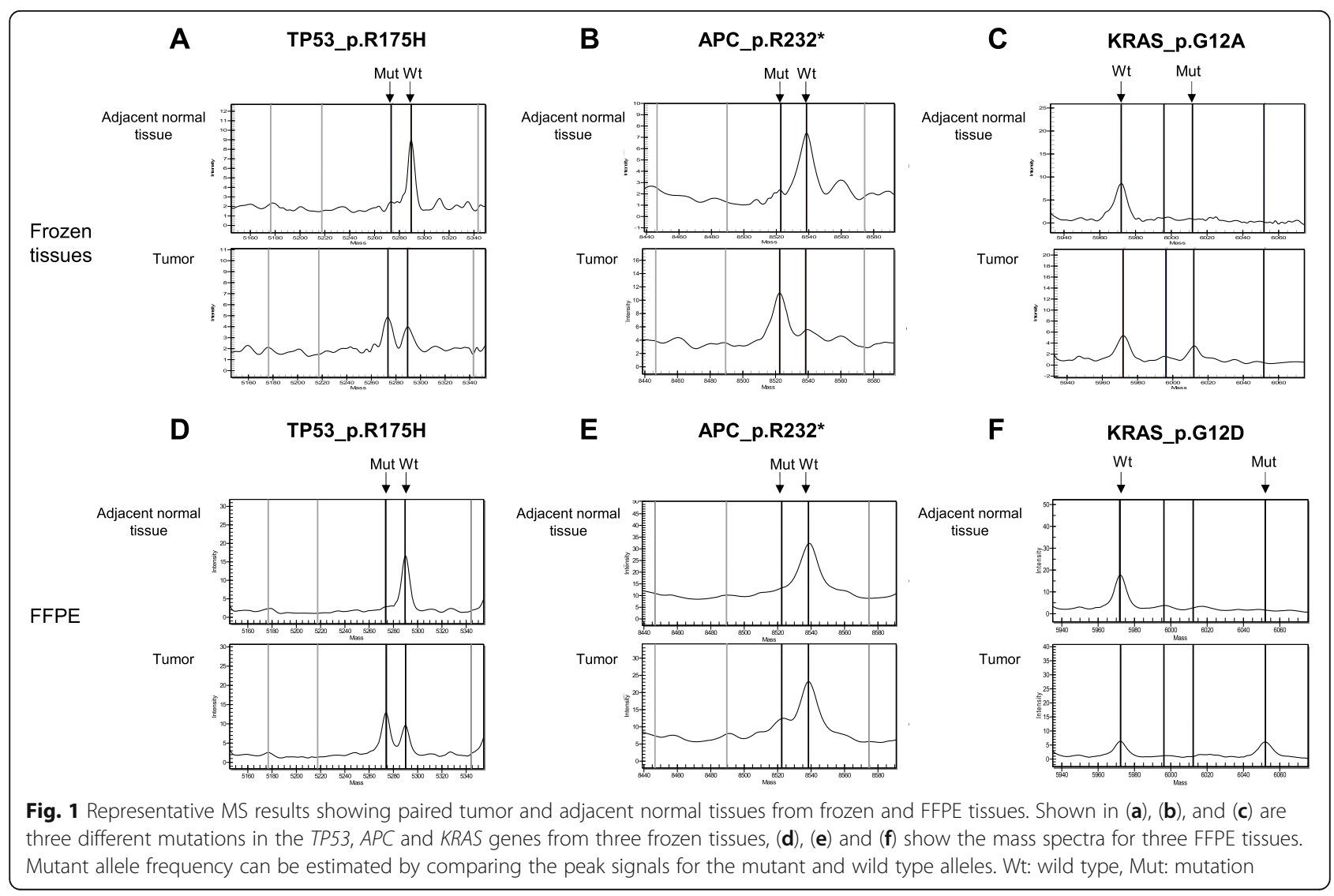




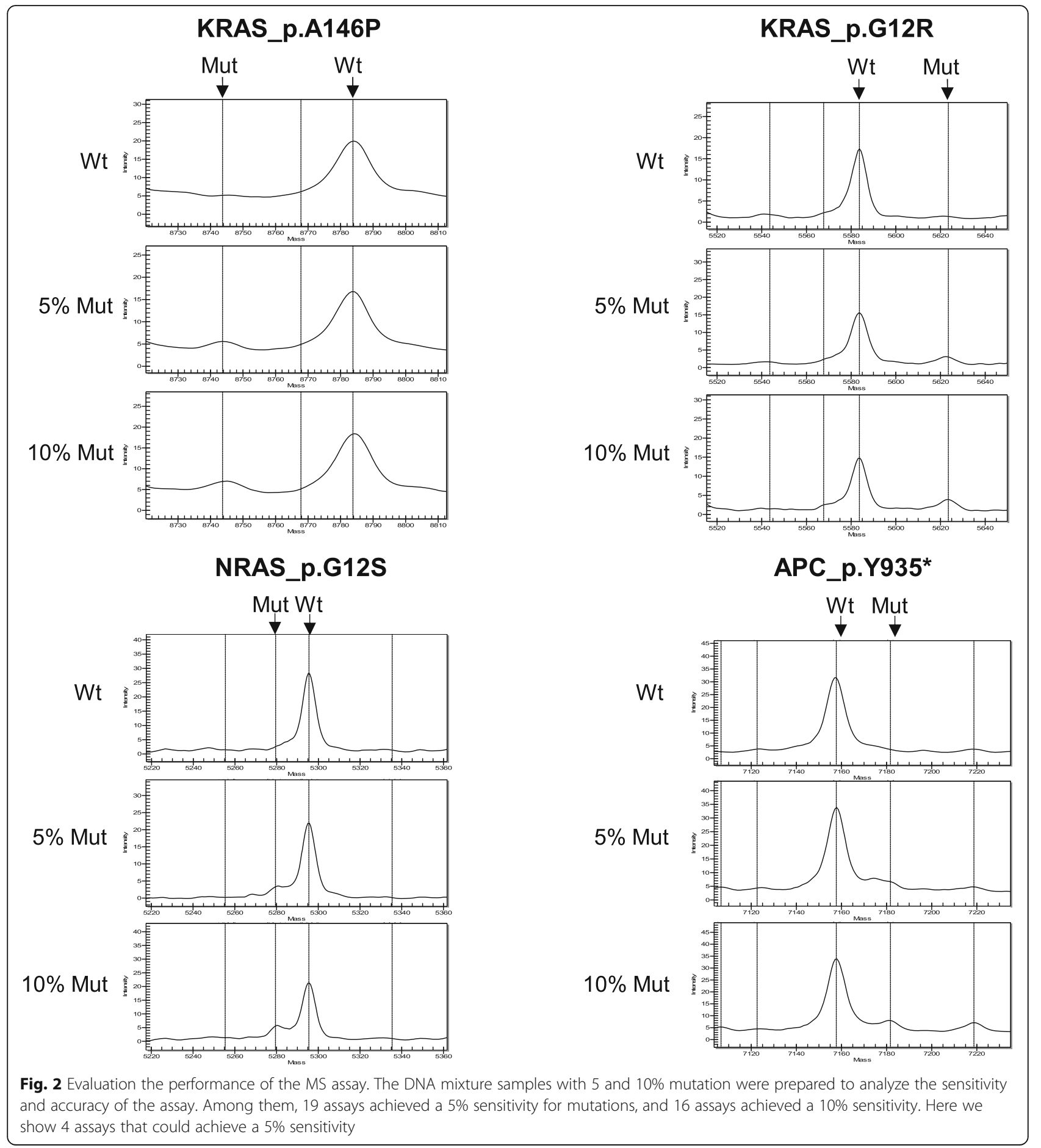

covariables, such as age, gender, clinical stage, location, differentiation, metastasis, treatment after surgery, and tumor size.

\section{Results}

Patients information

A total of 300 patients diagnosed with colorectal cancer between July 2015 and June 2019 were recruited.
Seventy one patients were excluded (see exclusion criteria in the methods section). Frozen tissues (paired tumor and adjacent normal tissues) from 136 patients, frozen tumor tissues from 47 patients, and formalin fixed paraffin embedded (FFPE) tissues (paired tumor and adjacent normal tissues) from 46 patients with CRC were analyzed. Table 1 summarizes the patients' baseline characteristics, tumor stage, location, differentiation, 
size, follow-up treatment after surgery and tumor marker (CEA) level.

\section{Selection of somatic mutations and multiplex assay design}

Somatic mutations for CRC were chosen based on their prevalence, and biological/clinical relevance. The final mutation panel consists of 299 mutations from 109 genes (Additional file 1: Supplementary Table 1).

We designed an 8-well multiple assay for a panel of 299 mutations (36-plex in well 1 and 2, 34-plex in well 3 and 5, 30-plex in well 4, 29-plex in well 6, 26-plex in well 7, and 12-plex in well 8) for MALDI-TOF MS analysis. The sequences of PCR primers and extension primers are provided in Additional file 1: Supplementary Table 2. Wild-type and mutant alleles were then discriminated by molecular weights of the extension products measured by MALDI-TOF MS (example results shown in Fig. 1).

To determine the sensitivity of the assays, we constructed plasmids for 35 different mutations. Plasmid mutations were confirmed by Sanger sequencing. Mixtures of plasmids containing wild-type and mutant sequences to mimic samples with 5 and 10\% mutation frequencies were prepared to analyze the sensitivity and accuracy of the assay. Among them, 19 assays achieved a 5\% sensitivity for mutations, and 16 assays achieved a 10\% sensitivity (Fig. 2 and Supplement figure 1).

\section{Mutation profiles of $\mathbf{2 2 9}$ patients from frozen and FFPE tissues}

Using the multiplex assay, we analyzed 411 samples from 229 patients (319 freshly frozen tissues from 183 patients and 92 FFPE samples from 46 patients) (Fig. 3). In the frozen tissue cohort, we identified and quantified 52 different somatic mutations in 107 patients. The most frequently mutated genes were KRAS (52 patients,
28.4\%), TP53 (48 patients, 26.2\%) and APC (32 patients, 17.5\%). We chose 20 mutations from 31 patients for Sanger sequencing validation. Sanger Sequencing showed complete concordance with MALDI-TOF MS (Additional file 2: Supplementary Figure 2).

In the cohort with 46 paired FFPE tissues (tumor and adjacent normal tissues), we first performed histopathological analysis with H\&E staining (Supplement figure 3). With the multiplex MS assay, we detected a total of 39 mutations in 35 samples. Similarly, APC, TP53, and KRAS were most frequently mutated. We chose 15 different mutations (19 total mutations) from 13 patients for Sanger sequencing validation (Additional file 2: Supplementary Figure 4). Eighteen of the 19 mutations (95\%) were validated successfully. Samples chosen for validation, as well as sequences of PCR primers and sequencing primers, are provided in Additional file 1: Supplementary Table 3.

Both frozen and FFPE tissues are commonly used for molecular pathology analysis. Tissue sampling differences may affect the somatic mutation frequencies in individual samples. For the three genes (TP53, APC, and KRAS) that are most commonly mutated in CRC, we found two genes (TP53 and $A P C$ ) showed higher mutation frequencies in the frozen tissues than the FFPE tissues. The average TP53 mutation frequencies were 50.9 and $38.3 \%$ for the frozen tissues and FFPE tissues, respectively ( $p=$ 0.006, Mann Whitney $U$ test). The average $A P C$ mutation frequencies were 47.5 and $26.8 \%$ for the frozen tissues and FFPE tissues, respectively ( $p=$ 0.005, Mann Whitney U test).

We next examined the association between the molecular alterations and patient characteristics (Table 2). Among the 142 patients with at least one somatic mutation identified, we found that the 63 patients without a

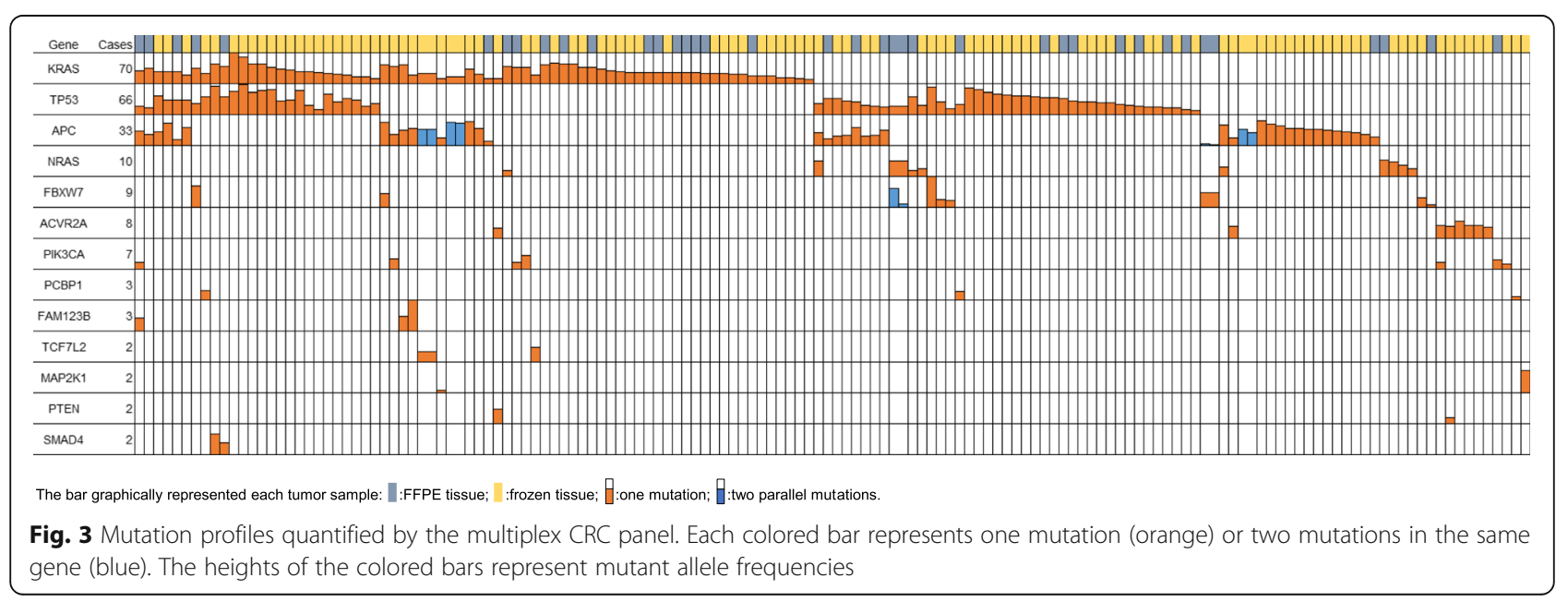


Table 2 Patient characteristics in different molecular subgroups

\begin{tabular}{|c|c|c|c|c|c|c|c|c|c|c|c|c|}
\hline & $\begin{array}{l}\text { With any } \\
\text { mutation }\end{array}$ & $\begin{array}{l}\text { No } \\
\text { mutation }\end{array}$ & $P$ value & $\begin{array}{l}\text { With } \\
A P C \\
\text { mutation }\end{array}$ & $\begin{array}{l}\text { With other } \\
\text { mutation } \\
\text { but no } A P C \\
\text { mutation }\end{array}$ & $P$ value & $\begin{array}{l}\text { With } \\
\text { TP53 } \\
\text { mutation }\end{array}$ & $\begin{array}{l}\text { With other } \\
\text { mutation } \\
\text { but no } \\
\text { TP53 } \\
\text { mutation }\end{array}$ & $P$ value & $\begin{array}{l}\text { With RAS } \\
\text { mutation }\end{array}$ & $\begin{array}{l}\text { With other } \\
\text { mutation } \\
\text { but no } R A S \\
\text { mutation }\end{array}$ & $P$ value \\
\hline Patients - no. & 142 & 87 & & 41 & 101 & & 66 & 76 & & 79 & 63 & \\
\hline \multicolumn{13}{|l|}{ Age } \\
\hline $\begin{array}{l}\text { Median } \\
\text { (range) - yr }\end{array}$ & $\begin{array}{l}66 \\
(40-90)\end{array}$ & $\begin{array}{l}65 \\
(31-87)\end{array}$ & & $\begin{array}{l}64 \\
(42-90)\end{array}$ & $67(40-82)$ & & $\begin{array}{l}65 \\
(44-82)\end{array}$ & $67(40-90)$ & & $\begin{array}{l}65 \\
(42-88)\end{array}$ & 67 (40-90) & \\
\hline Mean - yr & 66.3 & 65.2 & & 66.0 & 66.4 & & 65 & 67.4 & & 65.8 & 67.0 & \\
\hline$<50-$ no. & 11 & 9 & 0.508 & 5 & 6 & 0.845 & 5 & 6 & 0.185 & 5 & 6 & 0.517 \\
\hline 50-70- no. & 77 & 47 & & 21 & 56 & & 40 & 37 & & 46 & 31 & \\
\hline$>70$ - no. & 54 & 31 & & 15 & 39 & & 21 & 33 & & 28 & 26 & \\
\hline Gender - no. & & & 0.204 & & & 0.852 & & & 0.002 & & & 0.096 \\
\hline Male & 85 & 60 & & 24 & 61 & & 49 & 36 & & 43 & 42 & \\
\hline Female & 57 & 27 & & 17 & 40 & & 17 & 40 & & 36 & 21 & \\
\hline $\begin{array}{l}\text { Clinical stage - } \\
\text { no. }\end{array}$ & & & 0.041 & & & 0.631 & & & 0.204 & & & 0.019 \\
\hline । & 35 & 18 & & 12 & 23 & & 21 & 14 & & 24 & 11 & \\
\hline$\|$ & 37 & 32 & & 12 & 25 & & 18 & 19 & & 13 & 24 & \\
\hline III & 49 & 33 & & 11 & 38 & & 18 & 31 & & 31 & 18 & \\
\hline IV & 21 & 4 & & 6 & 15 & & 9 & 12 & & 11 & 10 & \\
\hline $\begin{array}{l}\text { Location } \\
\text { sampled - no. }\end{array}$ & & & 0.062 & & & 0.266 & & & 0.213 & & & 0.136 \\
\hline Rectum & 117 & 60 & & 35 & 82 & & 57 & 60 & & 70 & 47 & \\
\hline Left Colon & 8 & 11 & & 1 & 7 & & 2 & 6 & & 2 & 6 & \\
\hline Right Colon & 9 & 12 & & 1 & 8 & & 2 & 7 & & 3 & 6 & \\
\hline $\begin{array}{l}\text { Rectosigmoid } \\
\text { Junction }\end{array}$ & 8 & 4 & & 4 & 4 & & 5 & 3 & & 4 & 4 & \\
\hline $\begin{array}{l}\text { Differentiation } \\
\text { - no. }\end{array}$ & & & 0.892 & & & 0.128 & & & 0.156 & & & 0.400 \\
\hline Well & 8 & 5 & & 0 & 8 & & 5 & 3 & & 6 & 2 & \\
\hline Moderate & 113 & 67 & & 36 & 77 & & 50 & 63 & & 60 & 53 & \\
\hline Poor & 16 & 12 & & 3 & 13 & & 11 & 5 & & 10 & 6 & \\
\hline Unknown ${ }^{a}$ & 5 & 3 & & 2 & 3 & & 0 & 5 & & 3 & 2 & \\
\hline Metastasis- no. & & & 0.017 & & & 1.000 & & & 0.815 & & & 0.814 \\
\hline $\begin{array}{l}\text { With } \\
\text { Metastasis }\end{array}$ & 21 & 4 & & 6 & 15 & & 9 & 12 & & 11 & 10 & \\
\hline $\begin{array}{l}\text { Without } \\
\text { Metastasis }\end{array}$ & 121 & 83 & & 35 & 86 & & 57 & 64 & & 68 & 53 & \\
\hline $\begin{array}{l}\text { Treatment after } \\
\text { surgery - no. }\end{array}$ & & & 0.405 & & & 0.133 & & & 0.611 & & & 1.000 \\
\hline $\begin{array}{l}\text { With adjuvant } \\
\text { therapy }\end{array}$ & 77 & 52 & & 26 & 51 & & 34 & 43 & & 42 & 35 & \\
\hline $\begin{array}{l}\text { Without } \\
\text { adjuvant } \\
\text { therapy }\end{array}$ & 63 & 33 & & 14 & 49 & & 31 & 32 & & 35 & 28 & \\
\hline N/A & 2 & 2 & & 1 & 1 & & 1 & 1 & & 2 & 0 & \\
\hline $\begin{array}{l}\text { Tumor size - } \\
\mathrm{cm}\end{array}$ & & & 0.332 & & & 0.066 & & & 0.598 & & & 0.479 \\
\hline $\begin{array}{l}\text { Median } \\
\text { (range) }\end{array}$ & $\begin{array}{l}4 \\
(1.5-13)\end{array}$ & $4(1.5-10)$ & & $\begin{array}{l}4 \\
(1.5-12)\end{array}$ & $\begin{array}{l}4.3 \\
(1.5-13)\end{array}$ & & $\begin{array}{l}4 \\
(1.5-11)\end{array}$ & $\begin{array}{l}4 \\
(1.5-13)\end{array}$ & & $\begin{array}{l}4 \\
(1.5-13)\end{array}$ & $\begin{array}{l}4 \\
(1.5-8.5)\end{array}$ & \\
\hline Mean & 4.4 & 4.2 & & 4.0 & 4.6 & & 4.3 & 4.5 & & 4.6 & 4.3 & \\
\hline
\end{tabular}


Table 2 Patient characteristics in different molecular subgroups (Continued)

\begin{tabular}{|c|c|c|c|c|c|c|c|c|c|c|c|c|}
\hline & $\begin{array}{l}\text { With any } \\
\text { mutation }\end{array}$ & $\begin{array}{l}\text { No } \\
\text { mutation }\end{array}$ & $P$ value & $\begin{array}{l}\text { With } \\
A P C \\
\text { mutation }\end{array}$ & $\begin{array}{l}\text { With other } \\
\text { mutation } \\
\text { but no } A P C \\
\text { mutation }\end{array}$ & $P$ value & $\begin{array}{l}\text { With } \\
\text { TP53 } \\
\text { mutation }\end{array}$ & $\begin{array}{l}\text { With other } \\
\text { mutation } \\
\text { but no } \\
\text { TP53 } \\
\text { mutation }\end{array}$ & $P$ value & $\begin{array}{l}\text { With RAS } \\
\text { mutation }\end{array}$ & $\begin{array}{l}\text { With other } \\
\text { mutation } \\
\text { but no RAS } \\
\text { mutation }\end{array}$ & $P$ value \\
\hline CEA - ng/mL & & & 0.057 & & & 0.703 & & & 0.491 & & & 1.000 \\
\hline $0.0-5.0$ & 87 & 63 & & 26 & 61 & & 39 & 48 & & 49 & 38 & \\
\hline$>5.0$ & 53 & 21 & & 14 & 39 & & 27 & 26 & & 30 & 23 & \\
\hline N/A & 2 & 3 & & 1 & 1 & & 0 & 2 & & 0 & 2 & \\
\hline
\end{tabular}

$P$ values were calculated with the use of $x^{2}$ test or Fisher exact test for categorical variables and Kruskal-Wallis test for continuous variables

${ }^{\text {a }}$ Reported as mucinous adenocarcinomas

N/A not available

RAS mutation exhibited different clinical stage distribution as compared with the 79 patients with RAS mutation $\left(p=0.019, x^{2}\right.$ test). TP53 mutations were more frequently found in male patients by univariate analysis $\left(p=0.002, \mathrm{x}^{2}\right.$ test $)$.

\section{Comparison between targeted NGS and MS assays}

We chose 13 patient samples and performed targeted NGS sequencing using xGen Pan-Cancer Panel V2.4. The NGS panel covers 532 genes. Deep sequencing was performed to have an average sequencing depth of 1400 . Among these 13 patients, the MS method identified 11 somatic mutations. Targeted NGS detected 14 mutations, including the 11 mutations detected by MS. Three mutations were identified only by NGS. These three discordant mutations were further analyzed by DNA cloning and capillary sequencing. Two mutations (KRAS c.G35A, $A P C$ _.C2626T) were verified by cloning and sequencing. One mutation (KRAS_c.G34A) was present at $3 \%$ by targeted NGS. We sequenced 37 clones and did not observe any mutant.

\section{Discussion}

We developed an 8-well, multiplexed assay based on automated MALDI-TOF mass spectrometry to detect 299 CRC related mutations in 229 southern China patients.

The selected 299 mutations cover the National Comprehensive Cancer Network (NCCN) guideline of colon cancer recommended gene list relevant to treatment and prognosis, such as KRAS, NRAS, BRAF V600E mutations [15-17]. The MALDI-TOF MS assay is sensitive and quantitative in analyzing somatic mutations, with extensive validation by capillary sequencing, as well as a headto-head comparison with a targeted NGS panel covering 532 genes. We analyzed both frozen tissues and FFPE samples as both sample types are commonly used for molecular pathology analysis. In our cohorts, we found the frozen tissues may contain higher tumor content as evidenced by higher mutation frequencies for TP53 and $A P C$, which may be due to sampling differences.
NGS-based methods can detect known and unknown mutations while the MALDI-TOF MS assay is more suitable to detect pre-selected, functionally relevant known mutations. The cost of the multiplex MS assay (about USD 60/sample) is substantially lower than targeted NGS (about USD $150 \sim 200 /$ sample). The MS approach is highly automated and suitable for high throughput analysis of larger sample size, making it suitable as a routine testing platform. The overall time needed for the MS assay is about $9 \mathrm{~h}$, with hands-on time of about $60 \mathrm{~min}$. The MS assay is also flexible in panel expansion to add more important mutations.

\section{Conclusions}

We have developed and validated a highly multiplexed assay for the quantification of 299 somatic mutations in colorectal cancer tissues, offering a tool for studying the biological and clinical significance of somatic mutations with large numbers of cancer tissues. The multiplex assay may also be useful in clinical management of colorectal cancer patients.

\section{Supplementary information}

Supplementary information accompanies this paper at https://doi.org/10. 1186/s12920-020-00804-y.

Additional file 1 Table S1. Mutation list of CRC panel. Table S2. Primer sequences for mutation detection by CRC panel. Table S3. Primer sequences for mutation validation by Sanger sequencing. (XLS $145 \mathrm{~kb}$ )

Additional file 2 Figure S1. MS assays could detect 5 and $10 \%$ mutations mixed by wild-type and mutant plasmids. Figure S2. Genomic alterations of frozen tissues were detected by MALDI-TOF MS and confirmed by Sanger sequencing (A-F). Figure S3. Diagnosis and histopathological determination of Formalin Fixation and Paraffin Embedding tumor tissues (A-U) were conducted by analysis of H\&E staining. Figure S4. Genomic alterations of FFTE tissues were detected by MALDI-TOF MS and confirmed by Sanger sequencing (A-F).

\section{Abbreviations}

MALDI-TOF MS: Matrix-assisted laser desorption/ionization-time of flight mass spectrometry; PCR: Polymerase chain reaction; qPCR: Quantitative PCR; KRAS: KRAS proto-oncogene, GTPase; TP53: Tumor protein p53; APC: APC, WNT signaling pathway regulator; EGFR: Epidermal growth factor receptor; TKI: Tyrosine kinase inhibitor; NRAS: NRAS proto-oncogene, GTPase; NGS: Next-generation sequencing; TCGA: The Cancer Genome Atlas; 
CRC: Colorectal cancer; AJCC: American Joint Committee on Cancer; H\&E: Hematoxylin-and-Eosin; ICGC: International Cancer Genome Consortium; SNV: Single Nucleotide Variation; SNPs: Single Nucleotide Polymorphisms; VAF: Variant Allele Frequency; CEA: Carcinoembryonic Antigen; TCF7L2: Transcription factor 7 like 2; PFS: Progress-free survival; NCCN: National Comprehensive Cancer Network; BRAF: B-Raf ProtoOncogene, Serine/Threonine Kinase

\section{Acknowledgements}

We would like to thank all the patients who participated in the study. We would like to thank the support from the doctors and nurses from Department of Colorectal and Anal Surgery, The First and Second Affiliated Hospital of Wenzhou Medical University. We also thank Mr. Jin Weijiang for his help in the final revision of the manuscript.

\section{Authors' contributions}

CD, SJ and CX conceived, designed, supervised the study and critically revised the manuscript. $W L, X W, C L, W H, M C 2, H Z, G C, L Y, X Z, F J$ collected the cases and helped in statistical analysis. JL1, DP, MC1, YH, MH, QS, JL2 and QL performed the laboratory work. JL3 and DP contributed to data analysis and interpretation of the results. All authors read and approved the final manuscript.

\section{Funding}

This work was supported by the National Natural Sciences Foundation of China (No. 81672922), Medical Health Science and Technology Project of Zhejiang Provincial Health Commission (No. 2017174160), Wenzhou Municipal Science and Technology Bureau (No. Y20160044), Innovation Discipline of Zhejiang Province in Nucleic Acid Molecular Diagnostics (No. 437201702G) and Key Discipline of Zhejiang Province in Medical Technology (First Class, Category A) (No.437601607).

\section{Availability of data and materials}

The datasets used and analyzed during the current study are available from the corresponding author on reasonable request. All sequencing files are available from the NCBI BioProject database (https://www.ncbi.nlm.nih.gov/ bioproject/PRJNA662695).

\section{Ethics approval and consent to participate}

The study was approved by the Clinical Research Ethics Committee of the First Affiliated Hospital of Wenzhou Medical University and Wenzhou Medical University (ref. no. 2016-161). Written informed consent was obtained from participants.

\section{Consent for publication}

Not applicable.

\section{Competing interests}

The authors declare that they have no competing interests.

\section{Author details}

${ }^{1}$ Department of Colorectal and Anal Surgery, The First Affiliated Hospital of Wenzhou Medical University, Wenzhou, Zhejiang Province, China. ${ }^{2}$ School of Laboratory Medicine and Life Sciences, Wenzhou Medical University, Wenzhou, Zhejiang Province, China. ${ }^{3}$ Key Laboratory of Laboratory Medicine, Ministry of Education, Wenzhou Medical University, Wenzhou, Zhejiang Province, China. ${ }^{4}$ Department of Radiotherapy and Chemotherapy, The First Affiliated Hospital of Wenzhou Medical University, Wenzhou, Zhejiang Province, China. ${ }^{5}$ Department of Gastroenterology, The First Affiliated Hospital of Wenzhou Medical University, Wenzhou, Zhejiang Province, China. ${ }^{6}$ Department of Coloproctology, The Second Affiliated Hospital and Yuying Children's Hospital of Wenzhou Medical University, Wenzhou, Zhejiang Province, China. ${ }^{7}$ Department of Pathology, The First Affiliated Hospital of Wenzhou Medical University, Wenzhou, Zhejiang Province, China. ${ }^{8}$ Department of Laboratory Medicine, The Second Affiliated Hospital and Yuying Children's Hospital of Wenzhou Medical University, Wenzhou, Zhejiang Province, China.
Received: 24 July 2019 Accepted: 24 September 2020

Published online: 02 October 2020

\section{References}

1. Stratton MR, Campbell PJ, Futreal PA. The cancer genome. Nature. 2009; 458(7239):719-24

2. Santos R, Ursu O, Gaulton A, Bento AP, Donadi RS, Bologa CG, Karlsson A, Al-Lazikani B, Hersey A, Oprea TI, Overington JP. A comprehensive map of molecular drug targets. Nat Rev Drug Discov. 2017;16(1):19-34.

3. Soria JC, Ohe Y, Vansteenkiste J, Reungwetwattana T, Chewaskulyong B, Lee KH, Dechaphunkul A, Imamura F, Nogami N, Kurata T, Okamoto I, Zhou C, Cho BC, Cheng Y, Cho EK, Voon PJ, Planchard D, Su WC, Gray JE, Lee SM, Hodge R, Marotti M, Rukazenkov Y, Ramalingam SS, Investigators F. Osimertinib in untreated EGFR-mutated advanced non-small-cell lung Cancer. N Engl J Med. 2018;378(2):113-25.

4. Lievre A, Bachet JB, Boige V, Cayre A, Le Corre D, Buc E, Ychou M, Bouche $O$, Landi $B$, Louvet $C$, Andre T, Bibeau F, Diebold MD, Rougier $P$, Ducreux M Tomasic G, Emile JF, Penault-Llorca F, Laurent-Puig P. KRAS mutations as an independent prognostic factor in patients with advanced colorectal cancer treated with cetuximab. J Clin Oncol. 2008:26(3):374-9.

5. Amado RG, Wolf M, Peeters M, Van Cutsem E, Siena S, Freeman DJ, Juan T, Sikorski R, Suggs S, Radinsky R, Patterson SD, Chang DD. Wild-type KRAS is required for panitumumab efficacy in patients with metastatic colorectal cancer. J Clin Oncol. 2008:26(10):1626-34.

6. Metzker ML. Sequencing technologies - the next generation. Nat Rev Genet. 2010;11(1):31-46.

7. Hutter C, Zenklusen JC. The Cancer Genome Atlas: creating lasting value beyond its data. Cell. 2018;173(2):283-5.

8. Zehir A, Benayed R, Shah RH, Syed A, Middha S, Kim HR, Srinivasan P, Gao J, Chakravarty D, Devlin SM, Hellmann MD, Barron DA, Schram AM, Hameed M, Dogan S, Ross DS, Hechtman JF, DF DL, Yao J, Mandelker $D L$, Cheng DT, Chandramohan R, Mohanty AS, Ptashkin RN, Jayakumaran G, Prasad M, Syed MH, Rema AB, Liu ZY, Nafa K, Borsu L, Sadowska J, Casanova J, Bacares R, Kiecka IJ, Razumova A, Son JB, Stewart L, Baldi T, Mullaney KA, Al-Ahmadie H, Vakiani E, Abeshouse AA, Penson AV, Jonsson P, Camacho N, Chang MT, Won HH, Gross BE, Kundra R, Heins ZJ, Chen HW, Phillips S, Zhang H, Wang J, Ochoa A, Wills J, Eubank M, Thomas SB, Gardos SM, Reales DN, Galle J, Durany R, Cambria R, Abida W, Cercek A, Feldman DR, Gounder MM, Hakimi AA Harding J, lyer G, Janjigian YY, Jordan EJ, Kelly CM, Lowery MA, LGT M, Omuro AM, Raj N, Razavi P, Shoushtari AN, Shukla N, Soumerai TE Varghese AM, Yaeger R, Coleman J, Bochner B, Riely GJ, Saltz LB, Scher HI, Sabbatini PJ, Robson ME, Klimstra DS, Taylor BS, Baselga J, Schultz N, Hyman DM, Arcila ME, Solit DB, Ladanyi M, Berger MF. Erratum: Mutational landscape of metastatic cancer revealed from prospective clinical sequencing of 10,000 patients. Nat Med. 2017;23(8):1004.

9. Malapelle U, Sirera R, Jantus-Lewintre E, Reclusa P, Calabuig-Farinas S, Blasco A, Pisapia P, Rolfo C, Camps C. Profile of the Roche cobas(R) EGFR mutation test v2 for non-small cell lung cancer. Expert Rev Mol Diagn. 2017;17(3):209-15.

10. Milosevic D, Mills JR, Campion MB, Vidal-Folch N, Voss JS, Halling KC, Highsmith WE, Liu MC, Kipp BR, Grebe SKG. Applying standard clinical chemistry assay validation to droplet digital PCR quantitative liquid biopsy testing. Clin Chem. 2018:64(12):1732-42.

11. Fleitas $T$, Ibarrola-Villava M, Ribas $G$, Cervantes A. MassARRAY determination of somatic oncogenic mutations in solid tumors: moving forward to personalized medicine. Cancer Treat Rev. 2016;49:57-64.

12. Cancer Genome Atlas N. Comprehensive molecular characterization of human colon and rectal cancer. Nature. 2012;487(7407):330-7.

13. Froyen G, Broekmans A, Hillen F, Pat K, Achten R, Mebis J, Rummens JL, Willemse J, Maes B. Validation and application of a custom-designed targeted next-generation sequencing panel for the diagnostic mutational profiling of solid tumors. PLoS One. 2016:11(4):e0154038.

14. Wang K, Li M, Hakonarson H. ANNOVAR: functional annotation of genetic variants from high-throughput sequencing data. Nucleic Acids Res. 2010; 38(16):e164

15. Di Nicolantonio F, Martini M, Molinari F, Sartore-Bianchi A, Arena S, Saletti P, De Dosso S, Mazzucchelli L, Frattini M, Siena S, Bardelli A. Wild-type BRAF is required for response to panitumumab or cetuximab in metastatic colorectal cancer. J Clin Oncol. 2008;26(35):5705-12. 
16. Kopetz S, McDonough SL, Morris VK, Lenz H-J, Magliocco AM, Atreya CE, Diaz LA, Allegra CJ, Wang SE, Lieu CH, Eckhardt SG, Semrad TJ, Kaberle K, Guthrie KA, Hochster HS. Randomized trial of irinotecan and cetuximab with or without vemurafenib in BRAF-mutant metastatic colorectal cancer (SWOG 1406). J Clin Oncol. 2017;35(4_suppl):520.

17. Van Cutsem E, Kohne CH, Lang I, Folprecht G, Nowacki MP, Cascinu S, Shchepotin I, Maurel J, Cunningham D, Tejpar S, Schlichting M, Zubel A, Celik I, Rougier P, Ciardiello F. Cetuximab plus irinotecan, fluorouracil, and leucovorin as first-line treatment for metastatic colorectal cancer: updated analysis of overall survival according to tumor KRAS and BRAF mutation status. J Clin Oncol. 2011;29(15):2011-9.

\section{Publisher's Note}

Springer Nature remains neutral with regard to jurisdictional claims in published maps and institutional affiliations.

Ready to submit your research? Choose BMC and benefit from:

- fast, convenient online submission

- thorough peer review by experienced researchers in your field

- rapid publication on acceptance

- support for research data, including large and complex data types

- gold Open Access which fosters wider collaboration and increased citations

- maximum visibility for your research: over $100 \mathrm{M}$ website views per year

At BMC, research is always in progress.

Learn more biomedcentral.com/submissions 